\title{
25th Anniversary of the Founding of The Geneva Association
}

\author{
by Julius Neave*
}

Without any doubt one of the highlights of my fifty four years in the insurance industry was my membership of the Geneva Association. This organisation was fortunate in having at its foundation three men of outstanding ability and foresight who were the inspiration for the launch of something quite new to the industry and which would undertake a continuing study of the constantly and rapidly changing aspects of risk and uncertainty in relation to insurance economics in particular and their relevance to the wider economic scene.

Raymond Barre as the founder President and Fabio Padoa who succeeded him together with Orio Giarini as the original Secretary General were, in their own inimatable styles, able to overcome the industry's innate dislike of innovation and establish an organisation with a unique role that was to be beneficial over the widest spectrum to the very many varied interests in international insurance.

It was my good fortune to follow Fabio Padoa as President from 1983 to 1986 by which time the Geneva Association had become well established. I inherited a going concern remarkable for the widespread interest in its activities by academics in many different parts of the world, for the rapid growth in its membership by insurers and for the efficiency and economy of its administration.

One of the most refreshing things about the Geneva Association in its early days was its willingness, indeed the emphasis which it laid on studies taking the longer term view. This was at a time when "short termism" was so fashionable, induced no doubt by the pressures of inflation which were widespread at the time, but which reduced horizons virtually to the next "bottom line". I have always believed that this was a most damaging policy for insurance interests which are of course long term in their essence. Unfortunately however governments were as much hooked on "short termism" as commerce and escape from this damaging attitude was far from easy.

For many years insurers prospered in a climate of technological stability when changes in methods of manufacturing and administration were rare and slow. Several generations of underwriters could follow the experience of their predecessors and much underwriting was done by the "nose" for risk. Had the Geneva Association been born some fifteen years earlier it is just possible that the warning cones for the tempests of the eighties might have

\footnotetext{
* President of the Geneva Association from 1983-1986.
} 
been raised in time for the effects of the gathering speed of technological change to have been brought into the assessment of risk which was now to be affected by change on a quite unprecedente scale.

It is probably true that the speed of change is accelerating still and this makes the role of the Geneva Association one of continuing vital concern to the many interests it serves. If in its next twenty five years, the Geneva Association develops a similar degree of imaginative inspiration in its researches as it has so far then in the progressive globalisation of world wide commerce today the initiative taken to found the Association in 1973 will have been more than fully justified. 